\title{
Roosting, Nesting and Breeding Behaviour of Rose-Ringed Parakeet, Psittacula Krameri (Scopoli)
}

\author{
Syeda Azra Tariq ${ }^{1 *}$, Hina Zafar ${ }^{1}$, S. Shahid Shoukat ${ }^{2}$ \\ ${ }^{1}$ Vertebrate Pest Control Institute, Southern-zone Agricultural Research Centre Pakistan Agricultural Research \\ Council, Old Blocks 9 \& 10 University of Karachi, Karachi 75270 \\ ${ }^{2}$ Institute of Environmental Studies, University of Karachi, Karachi-75270, Pakistan
}

Corresponding Author: Syeda Azra Tariq, IVertebrate Pest Control Institute, Southern-zone Agricultural Research Centre Pakistan Agricultural Research Council, Old Blocks 9 \& 10 University of Karachi, Karachi 75270

\begin{abstract}
Roosting, nesting and breeding behaviour of rose-ringed parakeet was observed at four different locations in campus of the University of Karachi. Number, species, trunk diameter and location of dominant trees, and the number of parakeets leaving and returning to roosts at all locations were observed. Overall 103 nest cavities (average $9.92 \pm 1.89$ per location) were observed. Out of which 36 active nest cavities (average $2.77 \pm 0.96$ per location) were selected to observe breeding behaviour of the parakeets. Significant relationship was observed between the number of nests and the tree diameter. Number of eggs per nest ranged between 2 to 5 with an incubation period ranging between 19 to 25 days. Tree specie, trunk diameter, height of nest from the ground and breeding success (number of fledging chicks in nest) were observed. Fledging period of the chicks was observed to be 6 to 7 weeks. A perfect negative relationship was observed between the height and the number of nests. A negative relationship was observed between the nest height and fledging chicks.
\end{abstract}

Keywords: Psittacula krameri, rose-ringed parakeet, roosting, nesting and breeding behaviour.

\section{INTRODUCTION}

The rose-ringed parakeet, Psittacula krameri, is native to a broad band of sub-Saharan Africa and from India to Indo-China (Farsaw, 1973). It is found throughout Pakistan and India (Ali and Ripley, 1987). It has been introduced in a variety of areas around the world with varying degree of success (Long, 1991; Morgan, 1993; Pithon \& Dytham, 2001, 2002). Alexander the Great brought the first rose-ringed parakeet to Europe after seeing it on his travels through India, which was probably the first parakeet to be kept by man (Vriends, 1985).

The rose-ringed parakeet is a highly adaptable species and common in different habitats from deciduous woodland to arid scrubs and even in areas of dense human population. It is equally versatile in its feeding habits, eating fruits, berries, flowers, nectar, seeds and grains (Farsaw, 1989).

The rose-ringed parakeet is one of the favourite cage-birds, principally due to its ability to parrot and mimic (Hassan, 2001). However, in an agro-eco-system, it is considered an agricultural pest. It is abundant and a serious agricultural pest particularly where citrus fruits, sunflower and maize are important cash crops (Roberts, 1991). Many researchers worked on pestilence and food habit of the rose-ringed parakeet: Ramzan \& Toor (1973), Bashir (1978, 1981), Khan \& Ahmed (1983), Khan \& Wadood (1984), Shafi et al (1986), Khan \& Hussain (1990), Subramanya (1994), Bidari \& Kotikal (1996), Khan (1998, 2000, 2001).

Knowledge about the roosting, nesting and breeding behaviours of any avian pest specie helps in its effective management. Some early studies regarding roosting, foraging and breeding aspects of the rose-ringed parakeet were carried out in the central Punjab (Sarwar, 1987; Beg et al, 1988; Brooks et al, 1988; Iqbal, 1998; Khan, 2002). However, no significant study has been carried out on this subject in the province of Sindh. This paper reports the roosting, nesting and breeding behaviour of roseringed parakeet in the campus of the University of Karachi. The university campus has a very complex and rich flora of tall and old trees, which serve as communal roost and nesting sites for the 
rose-ringed parakeet. The preliminary findings of this study may be useful in effective parakeet management for agriculturists and may also be of interest for the lovers of nature and wild-life.

\section{Materials AND Methods}

A year-round study on roosting, nesting and breeding behaviour of the rose-ringed parakeet was undertaken in the campus of the University of Karachi. Four locations were deterministically selected for the study, namely, nursery, teaching departments, residential area and girls' hostel. Old, dense and tall trees provide roosting sites and nesting cavities to the parakeets at these locations. Observations were made during the entire study period. However, surveys for search of the active nest cavities were conducted during the breeding season (from December 2015 to June 2016). The survey was conducted by a team of eight person Composition, location, species and diameter of the trees at shoulder height (TDSH) bearing the nest cavities were recorded. In addition, Nests height was also noted. The morning and evening counting of the parakeets leaving and returning to the roosts was recorded. The observations were made on aiternate days in a week, from dawn to noon and from noon to dusk. Study areas were visited randomly throughout the study period to record activities of the breeding pairs. Observations regarding parakeet activities were conducted from suitable distance to avoid any disturbance to the parakeets. Field binoculars were used where necessary.

\section{RESULT AND DISCUSSION}

All four locations (nursery, teaching departments, residential area and girls' hostel) selected for the study were densely populated with old and tall trees of various species. A total of 2,350 trees were counted at these locations. As shown in Table 1, 1,553 trees (mean 388.25 \pm 161.80 / location) had TDSH <50", 679 trees $(169.75 \pm 62.16 /$ location) had TDSH 50-100" and 118 tress $(29.50 \pm 7.88 /$ location) had TDSH >100".

Table1. Dominant Trees Used for Communal Roosts by Parakeets in the Study Areas

\begin{tabular}{|c|c|c|c|c|}
\hline \multirow[t]{2}{*}{$\begin{array}{l}\text { Dominant } \\
\text { Trees }\end{array}$} & \multirow[t]{2}{*}{ Tree Location } & \multicolumn{3}{|c|}{$\begin{array}{l}\text { Tree Diameter at Shoulder Height } \\
\text { TDSH (in inches) }\end{array}$} \\
\hline & & $<50$ & $50-100$ & $>100$ \\
\hline \multirow{4}{*}{$\begin{array}{l}\text { Acacia nilotica (Babul or Kikar; Acacia } \\
\text { Arabica), Adenanthera pavonina (Ratan Gung; } \\
\text { Coral Wood), Albizzia lebbek (Siras; Lebbek } \\
\text { Tree), Azadirichta indica (Neem; Neem), } \\
\text { Cassia fistula (Amaltas; Laburnum), Cocos } \\
\text { nucifera (Narial; Coconut Plus), Cordia gharaf } \\
\text { (Gundni; Cordia), Cordia myxa (Lasoora; } \\
\text { Cordia), Delonix regia (Gul Mohar; Sunset } \\
\text { Tree), Eucalyptus (Safaida; Eucalyptus), } \\
\text { Eugenia jambolana (Jaman; Eugenia), Ficus } \\
\text { benghalensis (Bergad or Bar; Banyan), Ficus } \\
\text { glomerata (Gular; Ficus), Ficus religiosa } \\
\text { (Peepal; Ficus), Guaiacum officinale (Lignum; } \\
\text { Lignum vitae), Mangifera indica (Aam; } \\
\text { Mango), Manilkara hexandra (Kherni; } \\
\text { Mimusops), Manilkara zapota (Chikoo; } \\
\text { Sapodilla Plum), Phoenix dactylifera (Khajoor; } \\
\text { Date Palm), Roystonea regia (Palm; Royal } \\
\text { Palm), Tamarindus indica (Imli; Tamarind), } \\
\text { Terminalia catappa (Badam; Indian Almond), } \\
\text { Thespesia populnea (Paras Peepal; Bhendi } \\
\text { Tree) and Zizyphus jujuba (Ber; Zizyphus) }\end{array}$} & $\begin{array}{l}\text { Nursery } \\
\text { Area }\end{array}$ & 175 & 55 & 9 \\
\hline & $\begin{array}{l}\text { Teaching } \\
\text { Departments }\end{array}$ & 830 & 334 & 45 \\
\hline & $\begin{array}{l}\text { Residential } \\
\text { Area }\end{array}$ & 428 & 195 & 26 \\
\hline & $\begin{array}{l}\text { Girls Hostel } \\
\text { Area }\end{array}$ & 120 & 95 & 38 \\
\hline \multicolumn{2}{|l|}{ Total Number of Trees at All Four Locations } & 1553 & 679 & 118 \\
\hline \multicolumn{2}{|l|}{ Mean \pm SE } & $\begin{array}{l}388.25 \\
\pm 161.80 \\
\end{array}$ & $\begin{array}{l}169.75 \\
\pm 62.16 \\
\end{array}$ & $\begin{array}{r}29.50 \\
\pm 7.88 \\
\end{array}$ \\
\hline
\end{tabular}

The number of parakeets leaving from and returning to roosts at all locations was counted (Table 2). It was observed that the number of parakeets returning to the roosts increased usually, which may be due to the reason that during diurnal foraging for search of food, nest or roost, other parakeets of adjacent areas joined the returning flock. Communication among parakeets appeared to be well 
developed. Parakeets foraged in small flocks of four to six birds. During their activities they omitted calls and joined each other using audio-visual communication. In some cases, the returning number of parakeets was observed to be lesser than the leaving number of parakeets. It appeared that some parakeets found other opportunities or new companions. These findings corroborate with those of Brooks \& Hussain (1990) and Khan (2000).

Table2. Parakeets Leaving from and Returning to their Communal Roosts

\begin{tabular}{|l|l|l|}
\hline Month & $\begin{array}{l}\text { Leaving } \\
(\text { Mean } \pm \text { SE) }\end{array}$ & Returning (Mean \pm SE) \\
\hline Jan & $98 \pm 1.08$ & $123 \pm 2.20$ \\
\hline Feb & $125 \pm 2.24$ & $144 \pm 1.60$ \\
\hline Mar & $297 \pm 3.80$ & $311 \pm 3.00$ \\
\hline Apr & $332 \pm 1.84$ & $304 \pm 1.28$ \\
\hline May & $408 \pm 2.00$ & $475 \pm 2.14$ \\
\hline Jun & $395 \pm 4.09$ & $330 \pm 3.09$ \\
\hline Jul & $300 \pm 2.40$ & $341 \pm 1.71$ \\
\hline Aug & $220 \pm 1.88$ & $182 \pm 2.06$ \\
\hline Sept & $123 \pm 1.45$ & $98 \pm 1.09$ \\
\hline Oct & $75 \pm 1.24$ & $56 \pm 1.52$ \\
\hline Nov & $70 \pm 1.68$ & $73 \pm 1.01$ \\
\hline Dec & $59 \pm 0.98$ & $42 \pm 0.28$ \\
\hline
\end{tabular}

Nesting behaviour of parakeets was observed at all locations. Species and diameter of the trees bearing nest cavities was recorded (Table 3). Table 4 depicts the frequency distribution of the number of nests in relation to tree diameter. Overall 103 nest cavities were found in the study area: 77 in trees having TDSH <50", 22 in trees having TDSH 50-100" and 4 in trees having TDSH >100". Four categories of tree diameter were established while 3 categories of the number of nests were made to make an $\mathrm{R} \times \mathrm{C}$ contingency table 4 . The chi-square was calculated and found chi-square $=28.52$ with $6 \mathrm{df}$ and was found significant $(\mathrm{p} \leq 0.001)(\mathrm{G}=23.97)$. This shows a positive association between tree diameter and number of nests. Regression analysis revealed significant relationship between the number of nests and the tree diameter (Table 5). It seems that parakeets prefer young trees with TDSH $<50$ " for their soft-wood, size or any other reason. Moreover, it may be due to the reason that some birds (such as, mynah, wood-pecker and spotted-owlet) and even squirrel compete for nesting cavities in thick trees. This conforms to the findings of Siddiqui (1993) and Inam (1992).

Table3.Number of Nest Cavities at Different Locations in Various Tree Species

\begin{tabular}{|c|c|c|c|c|c|c|c|c|c|}
\hline \multirow{2}{*}{$\begin{array}{c}\text { Name of } \\
\text { Specie } \\
\text { Scientific } \\
\text { Local English }\end{array}$} & \multicolumn{4}{|c|}{ Location of Trees/Nest Cavities } & \multicolumn{2}{|c|}{ Nest Cavities } & \multicolumn{3}{|c|}{$\begin{array}{l}\text { Tree Diameter } \\
\text { (TDSH) in inches }\end{array}$} \\
\hline & $\begin{array}{c}\text { Nursery } \\
\text { Area }\end{array}$ & $\begin{array}{l}\text { Teaching } \\
\text { Deptts. }\end{array}$ & $\begin{array}{c}\text { Resid'l } \\
\text { Area }\end{array}$ & $\begin{array}{c}\text { Girls } \\
\text { Hostel } \\
\text { Area } \\
\end{array}$ & Total & Active & $<50$ & $\begin{array}{l}50- \\
100\end{array}$ & $\begin{array}{c}>10 \\
0\end{array}$ \\
\hline $\begin{array}{c}\text { Albizzia lebbek } \\
\text { Siras Lebbek } \\
\text { Tree }\end{array}$ & 1 & 0 & 1 & 0 & 2 & 0 & 1 & 1 & 0 \\
\hline $\begin{array}{c}\text { Azadirichta } \\
\text { indica } \\
\text { Neem Neem }\end{array}$ & 2 & 5 & 6 & 0 & 13 & 8 & 6 & 7 & 0 \\
\hline $\begin{array}{c}\text { Cassia fistula } \\
\text { Amaltas } \\
\text { Laburnum } \\
\end{array}$ & 3 & 7 & 4 & 1 & 15 & 5 & 7 & 8 & 0 \\
\hline $\begin{array}{c}\text { Delonix regia } \\
\text { Gul Mohar } \\
\text { Sunset Tree }\end{array}$ & 7 & 11 & 5 & 2 & 25 & 11 & 21 & 4 & 0 \\
\hline $\begin{array}{c}\text { Eucalyptus } \\
\text { specie } \\
\text { Safaida } \\
\text { Eucalyptus }\end{array}$ & 0 & 2 & 0 & 0 & 2 & 0 & 2 & 0 & 0 \\
\hline $\begin{array}{c}\text { Eugenia } \\
\text { jambolana } \\
\text { Jaman Eugenia }\end{array}$ & 2 & 0 & 8 & 0 & 10 & 4 & 10 & 0 & 0 \\
\hline
\end{tabular}


Roosting, Nesting and Breeding Behaviour of Rose-Ringed Parakeet, Psittacula Krameri (Scopoli)

\begin{tabular}{|c|c|c|c|c|c|c|c|c|c|}
\hline $\begin{array}{c}\text { Ficus } \\
\text { benghalensis } \\
\text { Bergad or Bar } \\
\text { Banyan }\end{array}$ & 1 & 0 & 0 & 3 & 4 & 0 & 0 & 0 & 4 \\
\hline $\begin{array}{c}\text { Ficus } \\
\text { glomerata } \\
\text { Gular Ficus } \\
\end{array}$ & 0 & 0 & 2 & 1 & 3 & 0 & 1 & 1 & 0 \\
\hline $\begin{array}{c}\text { Ficus religiosa } \\
\text { Peepal Ficus }\end{array}$ & 0 & 1 & 0 & 0 & 1 & 0 & 1 & 0 & 0 \\
\hline $\begin{array}{l}\text { Mangifera } \\
\text { indica } \\
\text { Aam Mango }\end{array}$ & 1 & 0 & 7 & 1 & 9 & 2 & 9 & 0 & 0 \\
\hline $\begin{array}{c}\text { Tamarindus } \\
\text { indica Imli } \\
\text { Tamarind }\end{array}$ & 0 & 2 & 1 & 0 & 3 & 1 & 3 & 0 & 0 \\
\hline $\begin{array}{c}\text { Terminalia } \\
\text { catappa } \\
\text { Wild almond } \\
\text { Indian Almond }\end{array}$ & 0 & 4 & 2 & 0 & 6 & 2 & 6 & 0 & 0 \\
\hline $\begin{array}{c}\text { Zizyphus } \\
\text { jujuba } \\
\text { Ber Jujube }\end{array}$ & 2 & 4 & 3 & 1 & 10 & 3 & 9 & 1 & 0 \\
\hline Total & 19 & 36 & 39 & 9 & 103 & 36 & 76 & 22 & 4 \\
\hline Mean \pm SE & $\begin{array}{l}1.46 \pm \\
0.5385\end{array}$ & $\begin{array}{l}2.77 \pm \\
0.9348\end{array}$ & $\begin{array}{l}3.00 \pm \\
0.7679\end{array}$ & $\begin{array}{l}0.69 \pm \\
0.2627\end{array}$ & $\begin{array}{l}7.92 \pm \\
1.8996\end{array}$ & $\begin{array}{l}2.77 \pm \\
0.9618\end{array}$ & $\begin{array}{l}5.85 \pm \\
1.5926\end{array}$ & $\begin{array}{l}1.69 \pm \\
0.7794\end{array}$ & $\begin{array}{c}0.31 \\
\pm \\
0.30 \\
77\end{array}$ \\
\hline
\end{tabular}

Table4. Frequency of Nest Distribution in Relation to Tree Diameter

\begin{tabular}{|c|c|c|c|}
\hline Tree Diameter (in inches) & No. of Nests & Tree Diameter (in inches) & No. of Nests \\
\hline 24 & 1 & 51 & 3 \\
\hline 25 & 1 & 52 & 2 \\
\hline 28 & 2 & 55 & 1 \\
\hline 31 & 2 & 56 & 2 \\
\hline 32 & 3 & 57 & 1 \\
\hline 34 & 1 & 61 & 1 \\
\hline 35 & 3 & 67 & 2 \\
\hline 36 & 3 & 68 & 1 \\
\hline 38 & 3 & 69 & 1 \\
\hline 39 & 4 & 70 & 1 \\
\hline 40 & 5 & 71 & 1 \\
\hline 41 & 4 & 72 & 1 \\
\hline 42 & 6 & 74 & 1 \\
\hline 43 & 3 & 77 & 1 \\
\hline 44 & 2 & 79 & 1 \\
\hline 45 & 11 & 82 & 1 \\
\hline 46 & 4 & 120 & 1 \\
\hline 47 & 2 & 145 & 1 \\
\hline 48 & 11 & 190 & \\
\hline 49 & 6 & 228 & \\
\hline
\end{tabular}

Table5. Regression Analysis: Nests versus Tree Diameter

The regression equation: nests $=3.66-0.0173$ tree diameter

\begin{tabular}{|c|c|c|c|c|}
\hline Predictor & Coef & SE Coef & T & P \\
\hline Constant & 3.6612 & 0.6689 & 5.47 & 0.000 \\
\hline width & -0.017304 & 0.008903 & -1.94 & 0.059 \\
\hline
\end{tabular}

$S=2.32469 R-S q=9.0 \% \quad R-S q(a d j)=6.6 \%$

The rose-ringed parakeets remained nearer to the nest cavities throughout the year generally. Active search for nests started between November and December. Male played active role in selection of the 
nest cavity and female (after occupying) widened it. Breeding pairs occupied nest cavities from December to January. Both partners defended the occupied nest cavities. Out of 103, thirty-six (36) active nest cavities were selected to study the breeding behaviour. It was observed that the nesting material only contained few wood chips. Egg laying was observed from February to April. The number of eggs (clutch size) ranged from 2 to 5 per nest. Eggs were pure white in colour, roundish oval in shape and measured closed to $30 \mathrm{~mm}$ x $20 \mathrm{~mm}$ in size. The incubation period observed was 19-25 days. Female generally stayed in the nest cavity before and during the incubation period. The male foraged around and allofed the female and chicks by regurgitation in nest cavities. Allofeeding and allopreening in the breeding pairs was observed throughout the breeding season, as was observed by some earlier researchers in Punjab (Sarwar, 1987; Inam, 1992; Iqbal, 1998; Khan, 2000).

Height of the active nest cavities and the number of fledging chicks therein were observed. Fledging period of chicks was observed to be six to seven weeks. The height played an important role in breeding success. The best height was three to five meters followed by five to seven meters. These findings may be justified by the fact that at lower than three to five meter height, some predators, for example, varanus and snake may eat eggs and chicks. Man can also take out chicks from the lower heights for pet trade. Whereas at height greater than five to seven meters, nests may be exposed to predator birds, rain water and sun heat. Dead chicks were observed in a nest cavity at height above seven meter, exposed to sun heat and light. With increase in height there was a significant decrease in the number of nests and fledging chicks in Table 6.

Table6. Breeding Success with Relation to Nest Height

\begin{tabular}{|c|c|c|c|c|}
\hline $\begin{array}{c}\text { Nest Height } \\
\text { (meters) }\end{array}$ & No. of Nests & $\begin{array}{c}\text { Nests with } \\
\text { Eggs }\end{array}$ & Nests with Hatchling Chicks & $\begin{array}{c}\text { Nests with Fledging } \\
\text { Chicks }\end{array}$ \\
\hline$<3$ & 11 & 8 & 13 & 2 \\
\hline $3-5$ & 10 & 9 & 8 & 8 \\
\hline $5-7$ & 9 & 9 & 2 & 6 \\
\hline $7-9$ & 6 & 6 & 7 & 0 \\
\hline
\end{tabular}

Interdependence between Nest Height, Number of Nests and Nests with Fledglings

\begin{tabular}{|c|c|c|c|}
\hline & Nest Height & No. of Nests & Nests with Fledging Chicks \\
\hline Nest Height & 1 & & \\
\hline No. of Nests & $\mathrm{r}_{12}=-0.956182887$ & 1 & \\
\hline Nests with Fledgling Chicks & $\mathrm{r}_{13}=-0.282842712$ & 0.507092553 & 1 \\
\hline
\end{tabular}

\section{ACKNOWLEDGEMENT}

The author expresses her thanks to the staff and residents of the University of Karachi for their help and cooperation, without which this study could have not been possible. Thanks are also extended to Mr. Javed Naseem of Southern-zone Agricultural Research Centre, Pakistan Agricultural Research Council, Karachi and Prof. S. M. Saleem of Defence Authority College of Business for their help in statistical analysis.

\section{REFERENCES}

[1] Ali, S. and Ripley, S. D. (1983). Handbook of the birds of India and Pakistan, Vol. I. Oxford: Oxford University Press.

[2] Ali, S. and Ripley, S. D. (1987). Compact handbook of the birds of India and Pakistan, $2^{\text {nd }}$ Edn. Mumbai: B.N.H.S.

[3] Bashir, E. A. (1978). Review of parakeet damage in Pakistan and suggested control methods. International proceedings seminar on bird pest problems in agriculture. pp. 22-26.

[4] Bashir, E. A., Siddiqui, S. and Ishrat, M., (1981). Investigation of some aspects related to the rose-ringed parakeet damage control in sunflower in Pakistan. Working paper. FAO- Pak/71/354.

[5] Bidari, V. B. and Kotikal, Y. K. (1996). A note on nature and extent of damage on mung bean due to the parakeet (Psittacula krameri scopoli). Karnataka Journal of Agricultural Sciences, Vol. 9 (3), pp 547-548.

[6] Forshaw, J. M. (1973, 1989). Parrots of the world, Lansdowns Editions. Willoughby, Australia.

[7] Khan, A. A. and Wadood, A. (1984). Food preference studies of rose-ringed parakeet, Psittacula krameri (Scopoli). Bull., Zool., 2: pp. 39-43.

[8] Khan, A. A. and Hussain, I. (1990). Parakeet, Psittacula krameri (Scopoli) damage to standing maize crop in Pakistan. Sarhad J of Agric, Vol.6, No.2, pp.185-191. 
[9] Khan, A. K. (1994). The gardener. Karachi: Jasmina, pp 483.

[10] Khan, H. A. (1998). Rose-ringed parakeet, Psittacula krameri, a serious threat to agriculture. Eclectus, 5: 39-41.

[11] Khan, H. A. (2000). Feeding regimen of rose-ringed parakeet, Psittacula krameri, in a maize agro system of central Punjab, Pakistan. Eclectus, 8: 9-11.

[12] Khan, H. A. (2001). Impact of trees as the nest in the roost of the rose-ringed parakeet, Psittacula krameri, in the agro systems of central Punjab, Pakistan. Eclectus, 10: 5-9.

[13] Long, J. L. (1991). Introduced birds of the world: The worldwide history, distribution and influence of birds introduced into new environments. London: Newtown Abbot.

[14] Morgan, D. H. W. (1993). Feral rose-ringed parakeets in Britain. British Birds, 86: 561-564.

[15] Piton, J. A. and Dytham, C. (2001). Determination of the origin of British feral rose-ringed parakeets. British Birds, 94: 74-79.

[16] Piton, J. A. and Dytham, C. (2002). Distribution and population development of introduced ring-necked parakeet in Britain between 1983 and 1998. Bird Study, 49: 110-117.

[17] Ramzan, M. and Toor, H. S. (1973). Damage to maize crop by rose-ringed parakeet Psittacula krameri (Scopoli) in the Punjab. J. Bombay. Nat. Hist. Soci. 70, pp. 201-204.

[18] Roberts, T. J. (1991). The Birds of Pakistan, Vol-I. Karachi: Oxford University Press

[19] Shafi, M. M., Khan, A. A. and Hussain, I. (1986). Parakeet, Psittacula krameri (Scopoli), damage to citrus fruits in Punjab, Pakistan. Bombay Nat. Hist. Society, Vol. 83 (2), pp. 438-444.

[20] Vriends, T. (1985). Cage and aviary birds. London: Ward Lock Limited, pp 136.

Citation: Syeda Azra Tariq, et.al.,"Roosting, Nesting and Breeding Behaviour of Rose-Ringed Parakeet, Psittacula Krameri (Scopoli)",International Journal of Research Studies in Zoology, vol. 5, no. 2, p. 20-25, 2019. DOI: http://dx.doi.org/10.20431/2454-941X.0502004

Copyright: () 2019 Authors. This is an open-access article distributed under the terms of the Creative Commons Attribution License, which permits unrestricted use, distribution, and reproduction in any medium, provided the original author and source are credited. 